\title{
Evaluation of Aerosol Emission during Different Agricultural Operations using Spectrometer
}

\author{
Mukesh Kumar Mehla* and Mukesh Jain \\ College of Agricultural Engineering \& Technology, CCSHAU, Hisar-125004, India \\ *Corresponding author
}

\section{A B S T R A C T}

\begin{tabular}{|l|}
\hline Ke y w o r d s \\
Dust emission, \\
Agricultural \\
emissions, Aerosol \\
spectrometer, \\
Spectrometry. \\
\hline Article Info \\
\hline Accepted: \\
22 February 2020 \\
Available Online: \\
10 March 2020 \\
\hline
\end{tabular}

This study was conducted to examine the emission of aerosols during different agricultural operation like mulching, ploughing etc. Grimm aerosol spectrometer (11-R LAS) was used to measure the emission levels in terms of respirable, thoracic, alveolic and particulate matter concentration $\left(\mathrm{PM}_{10}, \mathrm{PM}_{2.5}\right)$ on an experimental farm at Dabbda village in Hisar district of Haryana. Field was in dry condition after harvesting different operations were performed on the field emission was recorded at nose level of the tractor operator seated on his seat during different operations. The readings obtained were then compared with the NAQI standard and were found to be exceeding the safety limits. The average particulate matter concentration for ambient conditions, ploughing, mulching and straw chopping was $51,359,352$ and $513 \mu \mathrm{g} / \mathrm{m}^{3}$ respectively for $\mathrm{PM}_{10}$ and 18,130 , 156 and $201 \mu \mathrm{g} / \mathrm{m}^{3}$ respectively for $\mathrm{PM}_{2.5}$. Also average particles concentration in for $\mathrm{PM}_{10}, \mathrm{PM}_{2.5}$, thoracic, inhalable and aleovlic particle range for ploughing, mulching and straw chopping was considerably greater than ambient conditions.

\section{Introduction}

Aerosols are considered harmful for nature as well as human body. Causes health problems such as Cancer, Asthma, allergic alveolitis, bronchitis, farmer's hypersensitivity pneumonitis (FHP) and Visibility impairment (Parkes, 1994 \& Popendorf, 1985). High concentration of aerosol in environment causes moisture to condense around the dust particles which causes smog near the surface of earth which is toxic and also hampers the visibility. Farmer health concern should be should be first priority because country depends on its farmers for its food security. Air pollution and its associated ailments causes 3\% mortality in cardiopulmonary disease, $5 \%$ mortality in cancer of the trachea, bronchus and lungs, and $1 \%$ mortality in respiratory infections in children.

Agricultural operations generate $20 \%-25 \%$ of aerosols present in air (Cassel et al., 2003). Farmers health concerns have been a topic of negligence in developing and underdeveloped nation, lack of research in this field and 
undermining the threat lead to grave consequences, as a result many farmers are suffering from problems like Cancer, Asthma, Alveolitis, bronchitis, and Farmer's Hypersensitivity Pneumonitis (FHP) or Farmers lungs etc.

In absence of awareness and knowledge they are directly subjected to aerosols in the form of dusts, sprays, mists, smokes and fumes which effect there health adversely while spraying herbicide, pesticide, applying fertilizers and using implements which cause dust emissions.

Aerosols emitted during agricultural operations have great impact on environment as well health of the operator. Rising level particulate matter (PM) in the air and deteriorating air quality have become a major concern in recent times.

Tractor pulling tillage and other implements causes tremendous dust emission during these operation, operator usually tries to covers his face with cloth while operating to protect himself from dust in developing countries like India where there is dearth of knowledge and no proper protection masks or enclosed operator cabin on tractor for the operator.

Dust emission constitute mostly of aerosols present in field during driving operation. According to the International Standardization Organization (ISO, 1994), "Dust is small solid particle, conventionally taken as those particles size is below $75 \mu \mathrm{m}$ ".

According to EPA, $30 \mu \mathrm{g} / \mathrm{m}^{3}$ and $50 \mu \mathrm{g} / \mathrm{m}^{3}$ are safety limits for $\mathrm{PM}_{2.5}, \mathrm{PM}_{10}$ emission exposure for 24 hours (EPA, 2017). Aerosol spectrometer have been utilised to study and measure the $\mathrm{PM}_{10}, \mathrm{PM}_{2.5}$ and $\mathrm{PM}_{1}$ values in $\left(\mu \mathrm{g} / \mathrm{m}^{3}\right)$ and thoracic, inhalable and aleovlic particles concentration in $\left(\mu \mathrm{g} / \mathrm{m}^{3}\right)$ (Hiranuma, 2011).

\section{Materials and Methods}

The study was conducted on an experimental field in Dabbda (29.120188 N, 75.746396 E) village of Hisar district in Haryana, India. Soil was sandy loam and experiment was conducted on a winter morning with clear sky with wind speed $(3 \mathrm{~km} / \mathrm{hr})$ and Relative humidity was $65 \%$. Soil condition was dry, little stubbles were present in the field that are left after harvesting.

Grimm aersol spectrometer (Model: 11-R LAS) was used for measuring aerosol emission during different operations it uses the light scattering of single particles with a semiconductor laser as light source taking a measurement every 6 seconds. Collects, process and store the data with respect to time. $\mathrm{PM}_{2.5} \quad \& \quad \mathrm{PM}_{10}$ particulate matter emissions along thoracic, inhalable and aleovlic particles concentration $\left(\mu \mathrm{g} / \mathrm{m}^{3}\right)$ was studied for different field operation using implements namely mulcher, paddy straw chopper and a plough.

Grimm aerosol spectrometer was assembled then started by switching on plugging in and running for 30 secs for self-tests after making sure that different components are working fine. Measurements of ambient conditions on the field was taken but putting it on a random spot after that different implements were hitched the tractor. The operator was seated on the seat with aerosol spectrometer being held at level of the nose of the operator. The implement was used in field and readings of different parameter were taken. Same process was repeated for other implements.

\section{Results and Discussion}

Field emission recorded during different operations when compared with NAQI standards (NAQI, 2017) was found to be exceeding the prescribed safety limits. 
The safe limit of $\mathrm{PM}_{10}$ and $\mathrm{PM}_{2.5}$ were found to be crossed during the different field operations but were under safety limit for ambient condition on the field.

Average particulate matter concentration $\left(\mathrm{PM}_{10}\right.$ and $\left.\mathrm{PM}_{2.5}\right)$ recorded in field for different operation and ambient condition is given under Table 1. The average particulate matter concentration for ambient conditions, ploughing, mulching and straw chopping was $51,359,352$ and $513 \mu \mathrm{g} / \mathrm{m}^{3}$ respectively for $\mathrm{PM}_{10}$ and 18, 130, 156 and $201 \mu \mathrm{g} / \mathrm{m}^{3}$ respectively for $\mathrm{PM}_{2.5}$.

A graph of $\mathrm{PM}_{10}$ and $\mathrm{PM}_{2.5}$ concentration $\left(\mu \mathrm{g} / \mathrm{m}^{3}\right)$ during different operations with respect to time is given in Fig 1 and 2 respectively. Average particles concentration in $\left(\mu \mathrm{g} / \mathrm{m}^{3}\right)$ for $\mathrm{PM}_{10}, \mathrm{PM}_{2.5}$, thoracic, inhalable and aleovlic particle range obtained are given Table 2. Field emission recorded during different operations when compared with NAQI standards was found to be exceeding the safety limits for all the operations.

Emission in $\mathrm{PM}_{10}, \mathrm{PM}_{2.5}$, thoracic, inhalable and aleovlic particle range during ploughing, mulching and straw chopping was exceeding safety limits by great margin and also found to be more than ambient conditions in all the instances.

This research shows the need for protection equipments for tractor operator during different field operations to protect them from the harmful aerosols present in the field.

Table.1 NAQI safety limits and average particulate matter concentration $\mathrm{PM}_{10}$ and $\mathrm{PM}_{2.5}$ recorded in field for different operation and ambient condition $\left(\mu \mathrm{g} / \mathrm{m}^{3}\right)$

\begin{tabular}{|l|c|c|c|c|c|}
\hline $\begin{array}{l}\text { Particulate } \\
\text { Size }\end{array}$ & $\begin{array}{c}\text { Safety } \\
\text { limit }\end{array}$ & Ambient & $\begin{array}{c}\text { Ploughing } \\
\left(\boldsymbol{\mu g} / \mathbf{m}^{\mathbf{3}}\right)\end{array}$ & Mulching & Straw Chopping \\
\hline PM 10 & 100 & 51 & 359 & 352 & 513 \\
\hline PM 2.5 & 50 & 18 & 130 & 156 & 201 \\
\hline
\end{tabular}

Table.2 Average concentration $\left(\mu \mathrm{g} / \mathrm{m}^{3}\right)$ for $\mathrm{PM}_{10}, \mathrm{PM}_{2.5}$, thoracic, inhalable and aleovlic particle range particle range

\begin{tabular}{|l|c|c|c|c|c|}
\hline & PM10 & PM2.5 & $\begin{array}{c}\text { Inhalable } \\
\left(\boldsymbol{\mu g} / \mathbf{m}^{\mathbf{3}}\right)\end{array}$ & Thoracic & Alveolic \\
\hline Ambient & 51 & 18 & 64 & 50 & 25 \\
\hline Ploughing & 359 & 130 & 391 & 380 & 172 \\
\hline Mulching & 352 & 156 & 412 & 341 & 222 \\
\hline Straw Chopping & 513 & 201 & 397 & 509 & 248 \\
\hline
\end{tabular}




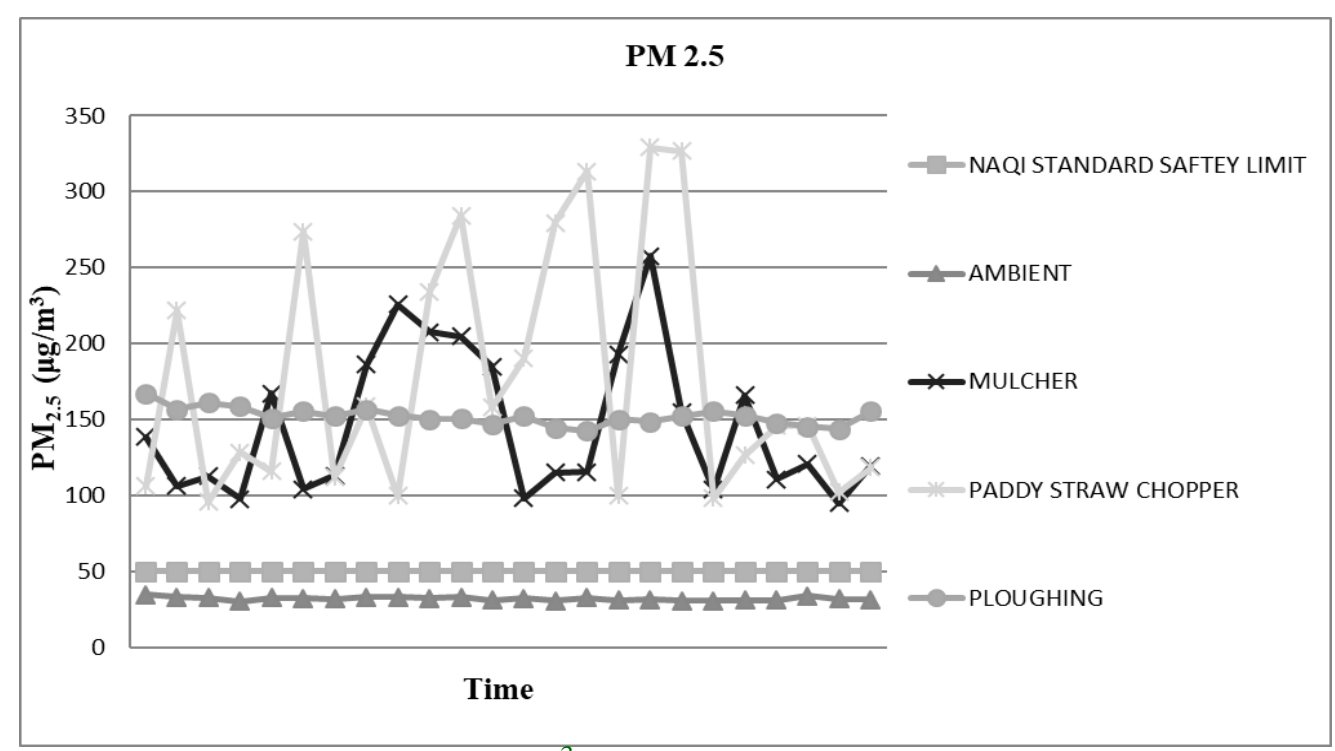

Fig.1 $\mathrm{PM}_{2.5}$ concentration $\left(\mu \mathrm{g} / \mathrm{m}^{3}\right)$ with respect to time for different operations, ambient condition and NAQI safety limit

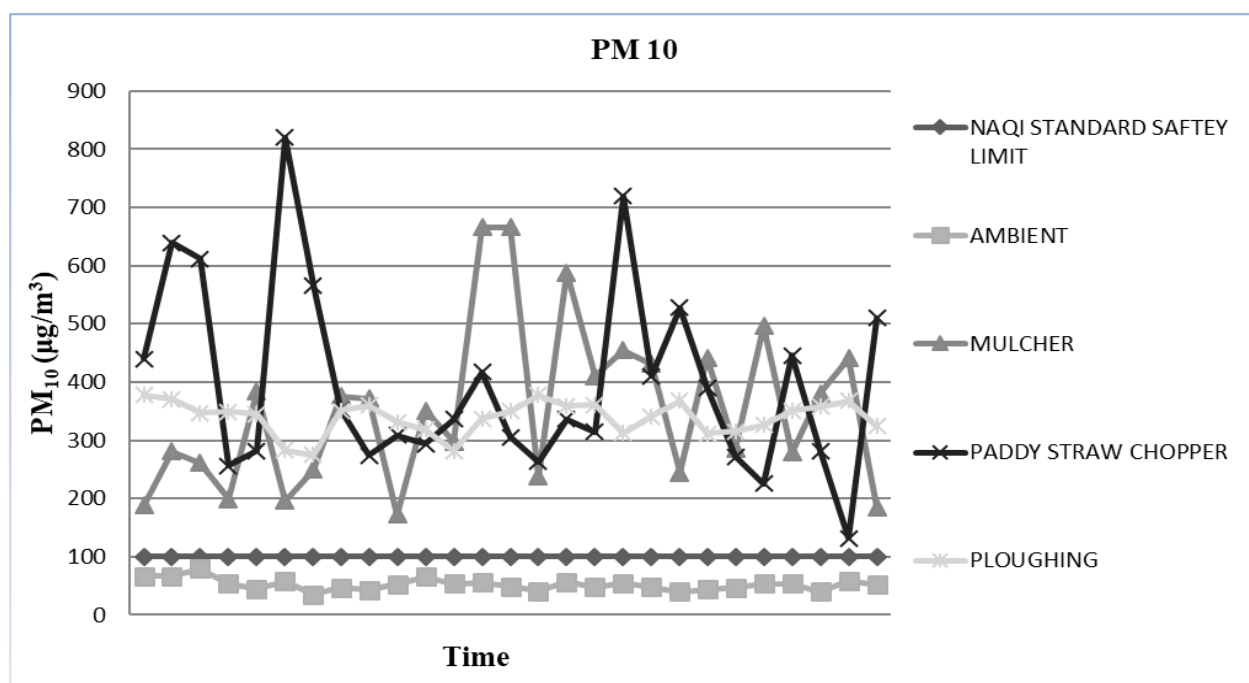

Fig.2 $\mathrm{PM}_{10}$ concentration $\left(\mu \mathrm{g} / \mathrm{m}^{3}\right)$ with respect to time for different operations, ambient condition and NAQI safety limit

\section{Acknowledgements}

This research conducted under the guidance of Er. Mukesh Jain, Assistant professor, Department of farm machinery and power Engineering, College of Agricultural Engineering and Technology, CCS Haryana Agricultural University, Hisar, who provided support during the project by making available equipments and machine required for the project.

\section{References}

Cassel, T., Trzepla-Nabaglo, K., Flocchini, R., PM10 emission factors for harvest and tillage of row crops. $12^{\text {th }}$ International Emission Inventory Conference "Emission Inventories Applying New Technologies". San Diego, USA. 120-124. 2003.

EPA (2017). National Ambient Air Quality Standards (Site: http://www.EPA.gov) 
Retrieved on March 16, 2017

Hiranuma, N., Brooks, S.D., Gramann, J. and Auvermann B.W., High concentrations of coarse particles emitted from a cattle feeding operation. Atmos. Chem. Phys., 2011, 11, 8809-8823,

ISO, Air Quality - Particle Size Fraction Definitions for Health-related Sampling. ISO Standard 7708. International Organization for Standardization (ISO), Geneva, 1995.
NAQI, National Air Quality Index. Ministry of Environment, Forest and Climate Change, GOI. Retrieved on March 16, 2017

Parkes W.R., Occupational Lung Disorders, 3rd. edition. Butterworth-Heinemann, UK, 1994

Popendorf, W., Donham, K.E., Easton D.N., Silk J. A., (1985) Synopsis of agricultural respiratory hazards. Am Indust Hyg Assoc., 1985, 46, 154-61.

\section{How to cite this article:}

Mukesh Kumar Mehla and Mukesh Jain. 2020. Evaluation of Aerosol Emission during Different Agricultural Operations using Spectrometer. Int.J.Curr.Microbiol.App.Sci. 9(03): 2795-2799. doi: https://doi.org/10.20546/ijcmas.2020.903.321 